\title{
Assessment of Diplodus spp. (Sparidae) nursery grounds along the rocky shore of Marseilles (France, NW Mediterranean)
}

\author{
ADRIEN CHEMINEE ${ }^{1,2,3}$, PATRICE FRANCOUR ${ }^{2}$ and MIREILLE HARMELIN-VIVIEN ${ }^{1}$ \\ ${ }^{1}$ Centre d'Océanologie de Marseille, UMR CNRS 6540, Université de la Méditerranée, Station marine d'Endoume, \\ 13007 Marseille, France. E-mail: adrien.cheminee@unice.fr \\ 2 Université de Nice-Sophia Antipolis, EA 4228 ECOMERS, Parc Valrose, 06108 Nice Cedex 2, France. \\ ${ }^{3}$ Centre d'Estudis Avançats de Blanes (CEAB, CSIC), C/ d'accés a la Cala St. Francesc, 14. 17300 Blanes, Girona, Spain.
}

SUMMARY: This work aimed at performing a large scale assessment of Diplodus spp. (Sparidae) nurseries along the rocky shore of Marseilles (France, NW Mediterranean) by locating and quantifying nursery microhabitats and estimating the settlement pattern along this shore in 2004. Nursery grounds of Diplodus spp. represented only $9 \%$ of the $52 \mathrm{~km}$-long rocky shore of Marseilles. Their location, shallow rocky habitats sheltered within coves, made them vulnerable to human-induced habitat transformations. D. vulgaris settled along this coast at the end of February 2004 and D. puntazzo settled a couple of months earlier. Maximum densities observed reached 215 and 67 ind./100 $\mathrm{m}$ for D. vulgaris and D. puntazzo respectively. The settlement rates were spatially variable. At a regional scale, lower settlement rates were observed within the south and centre zones, compared to those observed in the west, east, and the Marseilles Bay zones. Suitable nurseries along this shore seem insufficient for the replenishment of adult assemblages, which suggests that they depend on the migration of adults from other areas. Along the Marseilles rocky shore, coastal development projects leading to the destruction of habitats would represent a major threat to the Diplodus life cycle, which could be even greater than usual given the vulnerability and small size of the nurseries. These results show that it is necessary to protect these scarce local nursery habitats and manage other nearby nurseries to ensure the survival of fish at a critical life stage and the replenishment of adult assemblages.

Keywords: Diplodus, nursery microhabitats, settlement, settlers, juveniles, shallow rocky habitat, habitat transformation, coastal zone management.

RESUMEN: Evaluación de los Sitios de asentamiento de Diplodus SPP. (Sparidae) a lo largo de la costa rocosa de Marsella (Francia, Mediterráneo Noroccidental). - Este estudio tiene por objetivo realizar una evaluación a gran escala de las áreas adecuadas para el asentamiento de Diplodus spp. a lo largo de la costa rocosa de Marsella (Francia, Mediterráneo Noroccidental) a través del estudio de la ubicación y abundancia de estos microhábitats y del patrón de asentamiento durante el año 2004. Los microhábitats de asentamiento representaron tan sólo el $9 \%$ de los $52 \mathrm{~km}$ de las extensas costas rocosas de Marsella. Su ubicación en el interior de las calas, en substratos rocosos protegidos y a poca profundidad, los convierte en hábitats vulnerables a las transformaciones inducidas por el hombre. El asentamiento a lo largo de esta costa tuvo lugar a finales de febrero 2004 para D. vulgaris, y dos de meses antes para D. puntazzo. Las máximas densidades observadas por cada 100 metros de costa alcanzaron 215 y 67 individuos de D. vulgaris y D. puntazzo respectivamente. Las tasas de asentamiento fueron variables en el espacio. A escala regional, las tasas de asentamiento menores fueron observadas en las zonas sur y central. Los lugares de asentamiento adecuados a lo largo de esta costa parecieron insuficientes para abastecer las poblaciones adultas, lo que sugiere que éstas dependen de la migración de adultos desde otras áreas. La urbanización de la costa produciría destrucción de estos microhábitats, lo que pondría en peligro el ciclo vital de Diplodus, dada la vulnerabilidad y rareza de dichos microhábitats. Nuestros resultados mostraron la necesidad de proteger estos escasos hábitats de asentamiento y gestionar zonas de asentamiento a su alrededor para asegurar la conectividad entre hábitats, la supervivencia de determinadas fases críticas de los peces y el suministro de individuos a las poblaciones adultas.

Palabras clave: Diplodus, asentamiento, juveniles, hábitats rocosos, transformación de hábitats, gestión de áreas costeras. 


\section{INTRODUCTION}

Benthic and nektobenthic fish have a bipartite life cycle (Vigliola, 1998), with a pelagic larval phase and a more sedentary and benthic adult phase. In our study, settlement is defined as the arrival of early juvenile fish (referred to as "settlers") to benthic nursery areas after their pelagic larval phase. Recruitment corresponds to the later incorporation of these juvenile fish into adult populations after their settlement and survival in nurseries (referred to as "recruits") (Levin, 1994; Macpherson, 1998). "Juvenile" is used as a broader term that encompasses both settlers and recruits. The settlement rate can be defined as the number of new individuals joining the benthic habitat for a given nursery area. The recruitment level can be defined as the number of settlers remaining at the end of the post-settlement period, that is, those who survived and who will actually join adult assemblages (Macpherson, 1998).

The transition between pelagic and benthic stages is a key point of the species' life cycle (Brothers and MacFarland, 1981). Factors affecting the settlement and recruitment processes determine the renewal of populations and shape the structure of adult assemblages (Sano, 1997). To conserve marine resources, it is therefore a priority to study the factors affecting these processes. Among these, larval dispersion modalities (i.e. settler supply) and nursery habitat availability are key factors. Microhabitats are defined as subsets of biotic and abiotic habitat components; i.e. small-scale differences in habitat features which produce small-scale patchiness and different microhabitats within a few square meters (Chapman, 1995). Nurseries are defined as specific microhabitats whose characteristics are favorable for fish settlement. The characteristics of microhabitats appear to be a determining factor for settlement and recruitment success because settlers often have strict microhabitat requirements, as shown for sparids in the NW Mediterranean (Francour and Le Direac'h, 1994; García-Rubíes and Macpherson, 1995; Harmelin-Vivien et al., 1995; Guidetti and Bussotti, 1997; Le Direac'h and Francour, 1998; MacPherson, 1998; Vigliola et al., 1998; Planes et al., 1999). Other published data also provide information on microhabitat requirements for settlement of Blenniidae (Macpherson and Zika, 1999; Macpherson and Raventos, 2005), Labridae (García-Rubies and Macpherson, 1995; Raventos and Macpherson, 2005a, b), Pomacentridae (García-Rubies and Macpherson, 1995; Macpherson and Raventos, 2005), Serranidae and Mullidae (García-Rubies and Macpherson, 1995).

Nursery microhabitats, where the pelagic-benthic transition can occur, are thus key habitats. Their availability, structure and composition are essential for fish settlement and recruitment. A persistent concern in coastal management is that coastlines have nursery habitats for fish species but are greatly disturbed due to the direct impacts of human activities (Ballesteros, 2009). As a consequence, the species' life cycle and the conservation of adult assemblages may be affected if key habitats for juvenile fish settlement are transformed or destroyed (Harmelin-Vivien et al., 1995). In order to ensure conservation of fish assemblages, coastal management should focus on conserving these specific nursery habitats. Thus, scientific assessment must provide information on (i) the availability of these microhabitats (location, abundance), (ii) their larval supply (settlement rates), and (iii) the survival of settlers (recruitment level). Furthermore, it is also important to estimate the consequences of these key habitat transformations.

Previous studies, mainly performed in the NW Mediterranean, generally focused on microhabitats at a local scale, e.g. specific coves, and studied their intrinsic ecological functions. However, the availability of nurseries and settler supply patterns along the coast at a larger scale for a given area has never previously been assessed. We conducted a large-scale assessment of some Sparidae nurseries along the Marseilles 52 km-long rocky shore (NW Mediterranean, France). The Common two-banded seabream Diplodus vulgaris (Geoffroy Saint-Hilaire, 1817) and the Sharpsnout seabream D. puntazzo (Cetti, 1777) were chosen due to their high abundance, commercial value, and because their modalities of settlement and recruitment on shallow rocky bottoms are well described (e.g. García-Rubies and Macpherson, 1995; Harmelin-Vivien et al., 1995). The sea breams $D$. vulgaris and $D$. puntazzo are wellknown target fish for commercial and sport fisheries in the western Mediterranean. Adults are found between 0 and $150 \mathrm{~m}$ on rocky, sandy and seagrass bottoms. $D$. vulgaris forms small to large schools, while $D$. puntazzo is more solitary. Settlement takes place after a 15-30 day pelagic egg and larval phase (Vigliola, 1998) following reproduction events by adults in deep habitats. Settlers of both species are gregarious and share the same nursery grounds, usually located in shallow (less than $2 \mathrm{~m}$ deep) sheltered areas, with gently sloping substrates of gravel, pebbles, or boulders (Harmelin-Vivien et al., 1995). D. puntazzo settles in October-November, while settlers of $D$. vulgaris generally arrive in two settlement pulses, early November and January. Both species start to leave nursery grounds (recruitment) in May-June (Macpherson, 1998; Vigliola, 1998).

In order to perform a large scale assessment of the nurseries on the Marseilles rocky shore, we tested whether nurseries are common along the rocky shore and if they have homogenous abundances of settlers. Thus, this work aimed at (i) locating and (ii) quantifying Diplodus nursery grounds (microhabitat availability), and (iii) estimating the amount of settlers that settled during the winter and spring of 2004 (settlement rates) along this shore.

\section{MATERIALS AND METHODS}

\section{Study area}

Between January and May 2004, Diplodus nursery grounds were investigated at a regional scale at 23 


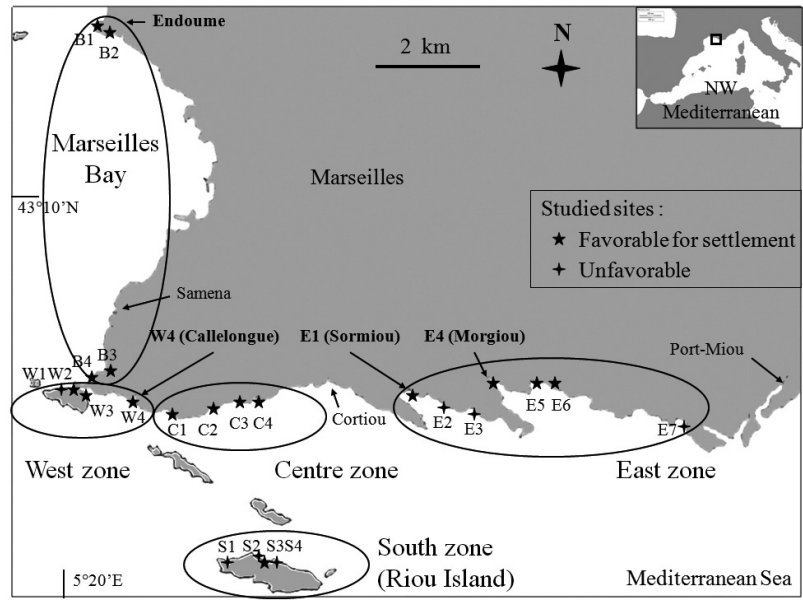

FIG. 1. - Study area: Marseilles Bay and the rocky shore; boundaries of the rocky shoreline: Samena and Port-Miou coves; five studied zones for the large scale study (bay, west, centre, south, east) representing a total of twenty three studied sites (favorable (stars) and unfavorable (crosses) sites for Diplodus settlement); three detailed study sites (Calanques) for the local scale study: E4 (Morgiou), E1 (Sormiou), W4 (Callelongue); Cortiou sewage.

randomly selected sites along the Marseilles Bay and along the $52 \mathrm{~km}$-long rocky shore of Marseilles, from Samena cove to Port-Miou cove, including the Riou archipelago (Fig. 1). According to previous knowledge of Diplodus spp. nursery grounds (Harmelin-Vivien et al., 1995), among these 23 sites, 16 sites could be considered a priori as favorable and 7 as unfavorable for settlement. There were geomorphologic differences along the bay and rocky shore, and sites were grouped into five distinct zones (Marseilles Bay, west, centre, south, and east; Fig. 1). The east zone (E) contained large wide coves open towards the south-east. The centre zone (C) contained small, narrow, south-west oriented coves. The south zone $(\mathrm{S})$ corresponded to the Riou archipelago, located at 1.8 nautical miles southward from the rocky shore. The west zone (W) was characterized by its intermediate position between the rocky shore and Marseilles Bay. Marseilles Bay (B) encompassed sites located within this large bay which was oriented westward. In order to complete the regional large scale study, a more detailed and extensive study was performed on a local scale in three of the sixteen favorable nursery sites of the rocky shore (coves termed "Calanques"; Fig. 1): Callelongue (site W4), Sormiou (site E1) and Morgiou (site E4).

\section{Location and quantification of nursery grounds}

The first step for assessing nurseries of this shore consisted in locating and quantifying favorable microhabitats for settlement, i.e. potentially suitable nursery grounds for settling Diplodus. Consequently, detailed mapping was first performed at sites W4, E1 and E4 (Fig. 1). This first mapping is referred to hereafter as local scale mapping. At the scale of each of these three Calanques, since we knew that nurseries would be found in a range of shallow waters (see ref. above), we mapped microhabitats within shallow depths (0-3 m). Mapping was carried out in situ, during one week in January 2004, by one single observer snorkeling along the entire shoreline of each of the three Calanques. The depth, slope, substratum type, biotic cover and exposure of the microhabitats of the superficial part of the infralittoral zone were recorded using the methodology previously described by Harmelin-Vivien et al. (1995). The location of the nursery grounds within these Calanques was then deduced and placed on the maps by comparing the recorded microhabitat characteristics with the previously described characteristics of Diplodus nursery grounds (Harmelin-Vivien et al., 1995). Then, at the regional scale, i.e. along the Marseilles Bay and the $52 \mathrm{~km}$ long rocky shoreline, we deduced the location of all other possible nurseries by analyzing topographic and geomorphologic maps. During the second phase of the study, in April 2004 (see next section), these deductions were validated by in situ snorkeling observations, as previously described. The total rocky shoreline and its portion of shoreline favorable for settlers were then measured with the help of a topographic map, ground truthed with field measurements. Thus, the proportion of the rocky shoreline favorable for settlement, and therefore acting as nursery grounds, was calculated.

\section{Quantification of Diplodus spp. settlers}

Once nursery grounds were located and quantified, their settler assemblages for 2004 were quantified. For a given year, settler density measured in situ can be used as an indicator of the settlement rate for a given area. The settler density refers to the amount of settlers counted for a given unit of shoreline length. For the local scale study (sites W4, E1, E4), three nursery replicates per Calanque were randomly chosen among those previously identified during the local scale mapping. (referred to as a, b, c; Fig. 2). In each nursery, Diplodus settler assemblages were censused weekly from 27 February to 14 May 2004. A total of 90 censuses were performed to study the temporal trends of settling for these two species (Cheminée, unpublished data). The maximum density observed for each replicate over this time frame was used as a measure of the settlement rate for the year 2004 (present study).

At the regional scale, large scale quantification of the 2004 settlement event was carried out by assessing the 23 sites along Marseilles Bay and the rocky shore (Fig. 1). Diplodus settler assemblages were censused in all 23 sites on the same date, between 21 and 23 April, 2004. Replicated counts were carried out at each site. A total of 79 censuses were performed, taking both species into account. The average density of each species observed for each of the 23 sites at this specific time was taken as a measure of the settlement rate for the year 2004 and used to assess the regional settlement pattern. 

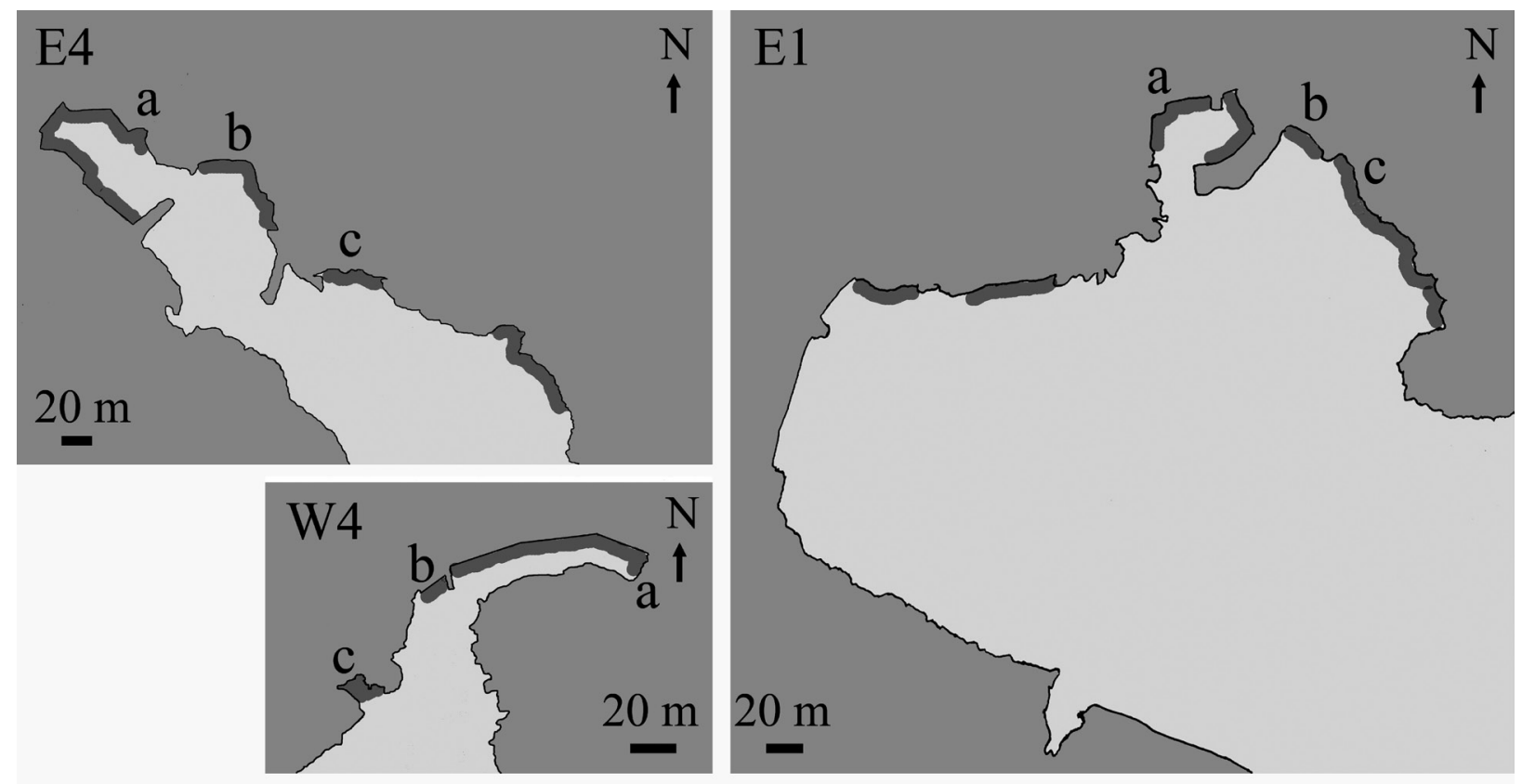

\section{Shoreline}

\section{Suitable nursery grounds}

FIG. 2. - Shaded areas represent the location of suitable microhabitats for Diplodus settlers (nursery grounds) in the three studied Calanques; E4 = Morgiou; E1 = Sormiou; W4 = Callelongue; Labels $(\mathrm{a}, \mathrm{b}, \mathrm{c})$ indicate the three monitored nursery replicates in each Calanque.

For both local (i.e. within the 3 Calanques) and regional (the 23 sites along the shoreline) scales, Diplodus settler assemblages were monitored by an Underwater Visual Census (UVC). Within each site, snorkeling at the same time of day (between 11 am and $3 \mathrm{pm}$ ), the diver swam slowly along the shoreline of the entire area. When individuals or groups of settlers were observed, the abundance and size of each species were recorded on a plastic slate. The total length (TL) of individuals was estimated with the help of fish silhouettes of different sizes pictured on the slate $(5 \mathrm{~mm}$ size classes). Thanks to its spatial configuration, each nursery was sampled completely by swimming parallel to the shoreline along a predetermined 5 meter-wide transect. Since nurseries were separated from each other by abrupt, unfavorable edges that would impede the circulation of settlers, each nursery and corresponding counts were independent from each other. Slow swimming helps to prevent the dispersal of settlers and allows them to be counted and their sizes estimated (Harmelin-Vivien et al., 1985, 1995; Vigliola et al., 1998). Macpherson (1998) evaluated the precision of this size estimating method as $+/-3.5 \mathrm{~mm}$ for Diplodus species. For the local scale study, within the three Calanques, where accurate maps of nurseries were obtained, counts were standardized according to length unit (density / length of shoreline). However, for the regional, large scale study, counts were standardized according to time unit and expressed as average settler density per 10 minute count. At the regional scale, during our censuses, we recorded the microhabitat char- acteristics of each site in situ using the same criteria as previously described (Harmelin-Vivien et al., 1995).

\section{Data analysis}

The normality assumption of density data was tested with the Levene test. Homogeneity of variances was tested with the Kolmogorov-Smirnov test. If tests were negative, data were $\log$ transformed $[\log (1+\mathrm{x})]$ or square root transformed. If not satisfactory, the Kruskal-Wallis or Mann-Whitney non-parametric test was used. At the local scale, mean maximum densities of settlers observed in each of the three Calanques (W4, E1, E4) were compared among Calanques or among species using a Kruskal-Wallis non-parametric test. The independent variable was either the Calanque (3-factor levels for each species) or the species (2-factor levels), while the dependant variable was the maximum density per nursery replicate for the considered species. At the regional scale, to study settlement patterns along the shoreline, the 23 sites surveyed were pooled according to their geographic position into the 5 zones previously described: east, central, south, west and Marseilles Bay (Fig. 1). The variability of Diplodus settler density recorded on a single date was studied with a Kruskal-Wallis test and a Student-NewmanKeuls post-hoc test, which is a pair wise comparison test used after the Kruskal-Wallis test to assess differences among groups. The independent variable was the zone (5-factor levels) and the dependant variable was the density for each site and species. 
TABle 1. - Maximum densities of settlers observed for Diplodus puntazzo and Diplodus vulgaris in the monitored nursery replicates (ind./100 m) and means within the local scale study sites (Calanques); SE, Standard error; CV, coefficient of variation.

\begin{tabular}{|c|c|c|c|c|c|}
\hline Site (Calanque) & Replicate & D. puntazzo & Mean \pm SE $(\mathrm{CV})$ & D. vulgaris & Mean \pm SE $(\mathrm{CV})$ \\
\hline E4 (Morgiou) & $\begin{array}{l}\text { E4-a } \\
\text { E4-b } \\
\text { E4-c }\end{array}$ & $\begin{array}{l}39.6 \\
24.8 \\
23.6\end{array}$ & $29.3 \pm 5.1(30)$ & $\begin{array}{l}54.9 \\
56.7 \\
35.4\end{array}$ & $49.0 \pm 6.8(24)$ \\
\hline E1 (Sormiou) & $\begin{array}{l}\text { E1-a } \\
\text { E1-b } \\
\text { E1-c }\end{array}$ & $\begin{array}{l}14.4 \\
37.1 \\
20.0\end{array}$ & $23.8 \pm 6.8(50)$ & $\begin{array}{c}47.6 \\
214.8 \\
77.8\end{array}$ & $113.4 \pm 51.4(76)$ \\
\hline W4 (Callelongue) & $\begin{array}{l}\text { W4-a } \\
\text { W4-b } \\
\text { W4-c }\end{array}$ & $\begin{array}{c}4.7 \\
20.1 \\
39.1\end{array}$ & $21.3 \pm 9.9(81)$ & $\begin{array}{c}12.2 \\
100.3 \\
109.4\end{array}$ & $73.9 \pm 31.0(73)$ \\
\hline E4, E1, W4 pooled & & & $24.8 \pm 4(48)$ & & $78.8 \pm 19.8(75)$ \\
\hline
\end{tabular}

The local and the regional settler quantification used two different parameters and corresponding units: maximum densities observed during the monitored time frame vs. densities observed for a given date; abundances per shoreline length and abundances per $10 \mathrm{~min}$. count. In the first case we aimed at quantifying the maximum hosting capacity of nurseries for this year, while in the second case we aimed at comparing the settlement rates among zones along the shoreline. For this second aim, recording densities in April allowed us to obtain an integrated measurement of the settlement event for this year because by this time the main settlement pulses were supposed to have occurred and to be pooled in the settler assemblages now present in nurseries.

\section{RESULTS}

\section{Location and quantification of nursery grounds}

At the scale of each of the three selected Calanques, nurseries were always located in the innermost part of each Calanque; Figure 2 gives their exact location.

Among the 23 sites surveyed along the bay and the rocky shore, all 16 a priori favorable sites had settlers, and all 7 a priori unfavorable sites did not have settlers. Along the total rocky shoreline, these field censuses allowed us to ground truth $3.1 \mathrm{~km}$ of a priori favorable shoreline for settlement over a total amount of a priori favorable shoreline, representing $4.3 \mathrm{~km}$ of a total rocky shoreline of $52 \mathrm{~km}$ long. Therefore, less than $9 \%$ of this coast displayed suitable nursery grounds for Diplodus spp.

\section{Quantification of Diplodus spp. settlers}

At the scale of each of the three Calanques, maximum densities of settled Diplodus observed in each replicate nursery during the four-month monitoring period displayed high local variability, except in E4 (see coefficient of variation (CV) in Table 1). Therefore, no significant differences in mean maximum densities of D. puntazzo (Kruskal-Wallis, $\mathrm{H}=1.72 ; P=0.633$ ) or D. vulgaris (Kruskal-Wallis, $\mathrm{H}=1.15 ; P=0.764$ ) were found between Calanques.

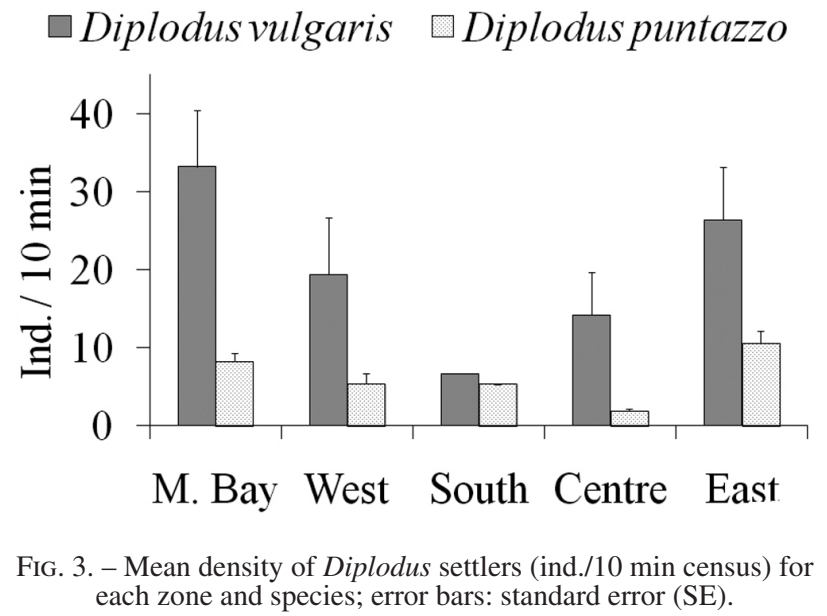

At the regional-large scale, settler density significantly differed between zones for $D$. puntazzo (Kruskal-Wallis, $\mathrm{H}=12.08 ; P=0.016$ ) (Fig. 3). $D$. puntazzo density was significantly higher in the east zone than in the centre zone $(P=0.0067)$ and higher in Marseilles Bay than in the centre zone $(P=0.0313)$. $D$. vulgaris densities showed a similar pattern but differences between zones were not significant (KruskalWallis, $\mathrm{H}=4.99 ; P=0.288$ ) due to high variability in the data from each zone (Table 2). For both species, the density observed was lowest in the south zone (the Riou archipelago), but this result relied on a single suitable site for settlement.

\section{Microhabitat characteristics, settler behavior and temporal partitioning}

The nursery characteristics of Diplodus settlers consisted in sheltered areas, characterized by shallow gently sloping bottoms composed of gravel, pebbles, or small boulders. High hydrodynamic conditions, abrupt slopes or the presence of vertical walls were unfavorable. Settlers were never observed on exclusively sandy bottoms or exclusively flat rocky flagstone. In the depth range surveyed (0-3 m) we noticed that $D$. vulgaris settlers were often dwelling deeper than $D$. 
TABLE 2. - Diplodus vulgaris and D. puntazzo settler densities in the 23 large scale study sites along the rocky shore. Number of 10 minute counts per site (n), settler density per 10 minutes (density/10 min).

\begin{tabular}{lcccc}
\hline Zone & Site & $\mathrm{n}$ & $\begin{array}{c}\text { D. vulgaris } \\
\text { density/10 min }\end{array}$ & $\begin{array}{c}\text { D. puntazzo } \\
\text { density/10 min }\end{array}$ \\
\hline Bay & B1 & 1 & 36.0 & 9.0 \\
Bay & B2 & 3 & 16.7 & 5.3 \\
Bay & B3 & 4 & 51.5 & 8.8 \\
Bay & B4 & 7 & 28.6 & 10.1 \\
West & W1 & 4 & 0.0 & 0.0 \\
West & W2 & 7 & 5.1 & 2.9 \\
West & W3 & 3 & 29.0 & 6.7 \\
West & W4 & 3 & 24.0 & 6.7 \\
South & S1 & 3 & 0.0 & 0.0 \\
South & S2 & 3 & 0.0 & 0.0 \\
South & S3 & 3 & 6.7 & 5.3 \\
South & S4 & 3 & 0.0 & 0.0 \\
Centre & C1 & 4 & 3.8 & 1.5 \\
Centre & C2 & 3 & 22.7 & 2.7 \\
Centre & C3 & 2 & 6.0 & 1.5 \\
Centre & C4 & 4 & 24.5 & 1.8 \\
East & E1 & 3 & 36.0 & 9.0 \\
East & E2 & 3 & 0.0 & 0.0 \\
East & E3 & 3 & 0.0 & 0.0 \\
East & E4 & 3 & 22.7 & 11.7 \\
East & E5 & 4 & 38.0 & 7.5 \\
East & E6 & 3 & 9.0 & 14.3 \\
East & E7 & 3 & 0.0 & 0.0 \\
\hline
\end{tabular}

puntazzo settlers, which were restricted to the very shallow areas. This was particularly obvious during days with higher hydrodynamic conditions, when $D$. vulgaris took refuge in deeper water while $D$. puntazzo stayed in the surf zone.

An ontogenetic evolution of microhabitat use was observed: newly settled individuals showed high fidelity to these microhabitat preferences, subsequently their home-range became larger over time and older juveniles displayed a wider range of microhabitat use. In May-June, older D. puntazzo juveniles (i.e. recruits) were even observed dwelling out of their nursery habitats, over deeper and different microhabitats, which we interpreted as them starting to leave the nursery habitats to actively join adults (i.e. recruitment phase).

The abundance of $D$. vulgaris settlers was higher than that of $D$. puntazzo, both at local (3 Calanques pooled) $(\mathrm{U}=6.16 ; P=0.013)$ and regional scales: in the Marseilles Bay and centre zone the relative abundance of $D$. vulgaris settlers was significantly higher than that of $D$. puntazzo (respectively $\mathrm{H}=5.33 ; P=0.02$ and $\mathrm{H}=5.40$ and $P=0.02$ ).

In February 2004, D. puntazzo settlers observed in nurseries, according to their size $(25-35 \mathrm{~mm})$, settled there a few months earlier. In the same month, settlers of $D$. vulgaris were smaller in size (15-20 mm TL). These data indicate that in $2004 \mathrm{D}$. vulgaris settlement occurred from mid-February to early March. Although this study was restricted to Diplodus puntazzo and D. vulgaris, it is worth mentioning that in Endoume cove (Fig. 1), early settlers (about $20 \mathrm{~mm} \mathrm{TL}$ ) of Diplodus sargus (Linnaeus, 1758) were observed in June 2004 in the same nursery microhabitat.

\section{DISCUSSION}

\section{Microhabitat characteristics, behavior of settlers and temporal partitioning}

Our observations of microhabitat characteristics where settlement was observed confirmed the previously described requirements of Diplodus spp. for benthic settlement in terms of the biotic and abiotic characteristics of their nursery grounds (Harmelin-Vivien et al., 1995): sheltered areas with shallow gently sloping bottoms composed of gravel, pebbles, or small boulders without vertical walls and overhangs.

Our observations of $D$. puntazzo settlers were consistent with results from previous studies that indicate October-November as a settlement period for this species (García-Rubies and Macpherson, 1995; Macpherson, 1998; Vigliola, 1998). Vigliola (1998) observed settlement of D. vulgaris between October and March in 1994 and 1996, with a settlement peak between mid-December and mid-January. It therefore seems that $D$. vulgaris settlement was delayed in 2004. Our observation of early settlers of D. sargus in June was in agreement with previous studies which highlighted that the same nursery grounds are successively used by different Diplodus species, demonstrating a temporal partitioning of habitat use (García-Rubies and Macpherson, 1995; Harmelin-Vivien et al., 1995; Macpherson, 1998; Vigliola, 1998).

Thus, the studied microhabitats, given their intrinsic value as key nursery habitats within fish life cycles and their successive use over time by several species, appear to be particularly important for Diplodus stock renewal.

\section{Quantification of nursery areas and settlement rates: a local and large-scale assessment}

Mapping of microhabitats highlighted that suitable nursery grounds represented a low proportion of the rocky shore (9\%) near Marseilles. Moreover, when present in a given Calanque (i.e. cove), nursery areas were found in the most vulnerable location: the innermost part of the cove, where human activities can cumulate and threat coastal habitat conservation, e.g. with direct impacts such as the destruction of microhabitats due to land being claimed from the sea (Meinesz et al., 2006). Consequently, human activities can affect Diplodus nursery grounds and settlement and thus the entire species life cycle through the replenishment of adult assemblages. These important biological areas for the Diplodus species are often targeted by coastal development programs, and therefore this issue is of special concern.

For a given year, settler density can be used as an indicator of the settlement rate in a given area. The settlement rate of Diplodus was highly variable at both scales studied: within Calanques (local scale) and between zones (regional scale). At the largest scale (amongst 
zones), the lower densities observed in 2004 in the south and centre zones, compared to those recorded in the east and Marseilles Bay zones (ratio 1 to 4), suggest that repeated observations are necessary in the future to verify whether this was a sporadic phenomenon or if a recurrent settlement deficit might occur in these zones. A settlement deficit was also observed in Hyères Bay and Port-Cros National Park (70 km apart eastward, Var shoreline, France, NW Mediterranean Sea), where Diplodus densities accounted respectively for only 30 to $5 \%$ of those observed in Marseilles Bay in the same year (Harmelin and Vigliola, 1998).

At the local scale (within a Calanque), such as in Callelongue (site W4) and to a lesser extent in Sormiou (E1), the high variability of the maximum settler densities, reflected in the CVs, suggests that settlement processes could depend on local environmental conditions, such as subtle differences in microhabitat complexity and temperature, which influence settler growth rate and mortality through predation (stage-duration hypothesis) as demonstrated by Vigliola (1998). In contrast, the lower variability of maximum settler density observed in Morgiou (E4) suggests that more homogenous environmental conditions shape its nurseries. The geomorphology of each Calanque (Fig. 2) may also determine the patterns observed, even if currently the main factors driving this variability remain unknown, and need further investigation.

On the large scale, the absence of significant difference in $D$. vulgaris density between zones may have been due to high density variability at the local scale within each zone. The occurrence of several successive settlement events, inducing local density variability, could mask large scale patterns. This hypothesis was supported by field observations which revealed successive cohorts of $D$. vulgaris settlers in at least one site (Cheminée, unpublished data).

Harmelin and Vigliola (1998) concluded that the settlement deficit observed in Port-Cros National Park was probably due to oceanographic currents that might have exported reproduction products (eggs and larvae) far away from breeding areas. Based on the results of the present study, we may hypothesize that the settlement patterns observed could also have been influenced by local geomorphology and currents.

Harmelin-Vivien et al. (1995) observed a recruitment deficit in the Riou archipelago (south zone) for five Sparidae species, including $D$. puntazzo and $D$. vulgaris. Moreover, the size structure of adult Diplodus assemblages around Riou archipelago shows a deficit of the smallest size class compared to the Marseilles Bay assemblages. In our study, fewer settlers of D. puntazzo were observed in the Riou archipelago in comparison with Marseilles Bay and the east zone. These results supported the idea of a recurrent Diplodus settlement deficit in the Riou archipelago. In order to confirm the hypothesis of a settlement deficit in the centre zone, it would be interesting to study the adult assemblage size structure further.
In conclusion, our large-scale assessment of the nurseries of the Marseilles rocky shore led us to reject our null hypothesis: nurseries were not common along the rocky shore and did not display homogenous abundances of settlers. This study (i) allowed us to localize Diplodus nursery grounds precisely within three main Calanques, (ii) quantified and highlighted the scarcity (9\%) and vulnerability of these nurseries along the entire rocky shore (low microhabitat availability), and (iii) gave an estimation of the settlement rates for 2004, suggesting a possible chronic settlement deficit in some zones (low settler supply). As a consequence, local nurseries alone might not be sufficient to replenish the adult assemblages of this shore, which may rely partly on the migration of adults or sub-adults first settling in other distant, more suitable areas, like the Marseilles Bay. Such a replenishment scenario has already been suggested by Harmelin-Vivien et al. (1995) and is similar to the one described for Port-Cros National Park by Harmelin and Vigliola (1998).

\section{Coastal management implications}

Nursery microhabitats are intrinsically important for species conservation and even more specifically for Diplodus because the same nursery grounds are successively used by different Diplodus species. In order to manage and protect Diplodus adult fish stocks along the rocky shore of Marseilles, our data (vulnerability of scarce local nurseries to coastal development) strongly indicate the need for protecting these nurseries. Nursery localizations should be taken into account for further integrated coastal management. Furthermore, since their scarcity may impair a full replenishment of adult assemblages, local coastal management needs to reinforce management in other nearby areas in order to allow distant nurseries to contribute to the renewal of the Diplodus adult assemblages along this rocky shore by supplying sub-adult migrants. In conclusion, all adult assemblages should have sufficient protected nursery grounds close enough to contribute to their replenishment (taking into account all relevant factors e.g. currents and distances). Reciprocally, when projects aimed at enhancing adult assemblages are devised (marine reserve, artificial reefs) they should be set next to or include nursery habitats in order to take advantage of the local adult reproductive potential (Francour et al., 2001).

\section{ACKNOWLEDGEMENTS}

This work was part of the Adrien Cheminée Research Master degree at the Université de la Méditerranée, Marseilles, France and contributed to the scientific monitoring program led by the "Groupement d'Intérêt Public des Calanques de Marseille à Cassis" (GIP Calanques), in charge of local coastal management coordination. We wish to thank Jean-Georges Harmelin for his scientific advice and help with field 
work. Laure Broquière from GIP Calanques was a constant support during the study. We are grateful to the GIP team, its former director J.L. Millot and to Bernard De Ligondes (Station marine d'Endoume) for logistic support. Isabel Calderón, Oriol Torrents, Nicolas Leblanc and Emmanuel Dieval provided a friendly and helpful work environment. We thank the Calanques' inhabitants for their hospitality during field work. Thanks to Isabel Calderón, Rhys Goodhead and two anonymous reviewers whose comments greatly improved the manuscript. Renata Ferrari Legorreta provided a lot of inspiration and support from the beginning to the end of this project.

\section{REFERENCES}

Ballesteros, E. - 2009. Is climate change the main driver of current community and landscape changes in the Mediterranean Sea? Oral communication. ASLO Aquatic Sciences Meeting 2009, 25-30 January 2009, Center of Congres Acropolis, Nice, France.

Brothers, E.B. and W.N. McFarland. - 1981. Correlations between otolith microstructure, growth, and life history transitions in newly recruited French grunts (Haemulon fiavolineatum (Desmaret), Haemulidae). Rapp. P.-v. Reun. Cons. int. Explor. Mer, 178: $369-374$.

Chapman, M.G. - 1995. Aggregation of the littorinid snail Littorina unifasciata in New South Wales, Australia. Mar. Ecol. Prog. Ser., 126: 191-202.

Francour, P., J.G. Harmelin, D. Pollard and S. Sartoretto. - 2001. A review of marine protected areas in the northwestern Mediterranean region: sitting, usage, zonation and management. Aquatic Conserv. Mar. Freshw. Ecosyst., 11: 155-188.

Francour, P. and L. Le Direac'h. - 1994. Recrutement de l'ichtyofaune dans l'herbier superficiel à Posidonia oceanica de la réserve naturelle de Scandola (Corse, Méditerranée nordoccidentale) : données préliminaires. Trav. sci. Parc. nat. reg. Corse, 46: 71-91.

García-Rubies, A. and E. Macpherson. - 1995. Substrate use and temporal pattern of recruitment in juvenile fishes of the Mediterranean littoral. Mar. Biol., 124: 35-42.

Guidetti, P. and S. Bussotti. - 1997. Recruitment of Diplodus annularis and Spondyliosoma cantharus (Sparidae) in shallow seagrass beds along the Italian coasts (Mediterranean Sea). Mar. Life, 7: 47-52.

Harmelin-Vivien, M. L., J.G. Harmelin, C. Chauvet, C. Duval, R. Galzin, P. Lejeune, G. Barnabé, F. Blanc, R. Chevalier, J. Duclerc and G. Lasserre. - 1985. Évaluation visuelle des peuplements et populations de Poissons : méthodes et problèmes. Rev. Ecol. (Terre Vie), 40: 467-539.

Harmelin-Vivien, M.L., J.G. Harmelin, and V. Leboulleux. - 1995. Microhabitat requirements for settlement of juvenile sparid fishes on Mediterranean rocky shores. Hydrobiologia, 301:
309-320.

Harmelin, J.G. and L. Vigliola. - 1998. Renouvellement des populations de sars (Diplodus spp.) du parc national de Port-Cros : évaluation du potentiel. Rap. Tech. Parc National Port-Cros, Programme Rech. 1996-97, 96.028.83400 PC.

Le Direac'h, L. and P. Francour. - 1998. Recrutement de Diplodus annularis (Sparidae) dans les herbiers de posidonie de la Réserve Naturelle de Scandola (Corse). Trav. sci. Parc. nat. reg. Corse, 57: 42-75.

Levin, P.S. - 1994. Fine-scale temporal variation in recruitment of a temperate demersal fish: the importance of settlement versus post-settlement loss. Oecologia, 97: 124-133.

Macpherson, E. - 1998. Ontogenetic shifts in habitat use and aggregation in juvenile sparid fishes. J. Exp. Mar. Biol. Ecol., 220: $127-150$.

Macpherson, E. and N. Raventos. - 2005. Settlement patterns and post-settlement survival in two Mediterranean littoral fishes: influences of early-life traits and environmental variables. Mar. Biol., 148: 167-177.

Macpherson, E. and U. Zika. - 1999. Temporal and spatial variability of settlement success and recruitment level in three blennoid fishes in the northwestern Mediterranean. Mar. Ecol. Prog. Ser., 182: 269-282.

Meinesz, A., F. Javel, S. Longepierre, Vaugelas, J. de and D. Garcia. - 2006. Inventaire et impact des aménagements gagnés sur le domaine marin - côtes méditerranéennes françaises. Univ. NiceSophia Antipolis, Lab. Ecomers: www.medam.org.

Planes, S., E. Macpherson, F. Biagi, A. Garcia-Rubies, J.G. Harmelin, M. Harmelin-Vivien, J.Y. Jouvenel, L. Tunesi, L. Vigliola and R. Galzin. - 1999. Spatio-temporal variability in growth of juvenile sparid fishes from the Mediterranean littoral zone. $J$. Mar. Biol. Ass. U. K., 79: 137-143.

Raventos, N. and E. Macpherson. - 2005a. Effect of pelagic larval growth and size-at-hatching on post-settlement survivorship in two temperate labrid fish of the genus Symphodus. Mar. Ecol. Prog. Ser., 285: 205-211.

Raventos, N. and E. Macpherson. - 2005b. Environmental influences on temporal patterns of settlement in two littoral labrid fishes in the Mediterranean Sea. Est. Coast. Shelf Sci., 63: 479-487.

Sano, M. - 1997. Temporal variation in density dependence: Recruitment and postrecruitment demography of a temperate zone sand goby. J. Exp. Mar. Biol. Ecol., 214: 67-84.

Vigliola, L. - 1998. Contrôle et régulation du recrutement des Sparidés (Poissons, Téléostéens) en Méditerranée : importance des processus pré-et post-installation benthique. Ph.D. thesis, Univ. Aix-Marseille II.

Vigliola, L., M. Harmelin-Vivien, F. Biagi, R. Galzin, A. GarcíaRubies, J.G. Harmelin, J. Y. Jouvenel, L. Le Direac'h-Boursier, E. Macpherson and L. Tunesi. - 1998. Spatial and temporal patterns of settlement among sparid fishes of the genus Diplodus in the northwestern Mediterranean. Mar. Ecol. Prog. Ser., 168: 45-56.

Scient. ed.: E. Macpherson.

Received September 29, 2009. Accepted July 6, 2010.

Published online January 10, 2011. 